\title{
Looking into the Gap: Land Use and the Tropical Forests of Southern Thailand
}

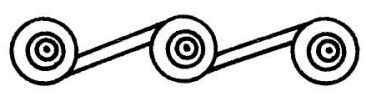

LISA KEALHOFER

The EMPHASIS ON THE ORIGINS Of RICE DOMESTICATION in Southeast Asia has been at the expense of a wider investigation of the development of food production strategies. Recently, as evidence from the Yangzi Valley has shifted the focus on rice origins to China, investigations of food production in mainland Southeast Asia have been further marginalized. Current arguments for the sudden appearance of rice agriculturalists in Southeast Asia in the late mid-Holocene neglect the longer-term development of local economies (Higham 1995, 1996; Higham and Lu 1998).

However, a growing body of evidence indicates that strategies for producing food in tropical forests were developed in Island Southeast Asia by the early Holocene if not before (Groube 1989; Haberle 1993; Latinis 2000). While alternative arboreal food production strategies have been investigated in Island Southeast Asia, it is argued here that early Holocene groups in Peninsular Thailand participated in a similar range of forest management strategies. Forest clearings appear to have been created and maintained in response to expanding lowland forests (and the closing of the forest canopy) in the early Holocene. The environmental data discussed reveal a continuous pattern of changing land-use strategies in contrast to apparent cultural gaps in the sequences from contemporary archaeological sites on the Malay Peninsula (Bellwood 1997). ${ }^{1}$

\section{SUBSISTENCE IN THE TROPICAL FOREST: THE HEADLAND} AND BAILEY DEBATE

In the 1980s, hunting and gathering in tropical forests became an increasingly contentious issue among anthropologists (Bailey et al. 1989; Headland 1986, 1987; Headland and Reid 1989). Counter to previous ideas that hunter-gatherers had long occupied most regions including tropical rainforests, Headland and Bailey (1991) suggested that hunting and gathering in tropical forests was dependent on the prior development of agriculture in adjacent areas. Their argument was based 
on a generalization that subsistence resources in tropical forests are too few to allow sustained hunting and gathering. Only through trade or cultivation could hunter-gatherers occupy tropical rainforests in the past or even today. This stimulated the debate on hunter-gatherer strategies and their time depth, with ethnographers, ethnoarchaeologists, and archaeologists searching for substantive evidence of pre-agricultural hunter-gatherers in tropical rainforests.

In numerous and wide-ranging counters to Headland's and Bailey's arguments (e.g., Endicott and Bellwood 1991; Brosius 1991; Dwyer and Minnegal 1991; Moran 1991; Stearman 1991) several major themes have emerged. First, critics argue that there is no typical "tropical rainforest," nor any "pristine" forest conditions to which hunter-gatherers first adapted. Tropical rainforests are highly variable both spatially and temporally. Second, this variability in resources, diversity, topography, extent of seasonality, and fauna shapes a wide range of subsistence strategies. Third, ethnographic and ethnohistoric examples of (potentially) independent hunter-gatherer rainforest subsistence regimes are common. Cumulatively, the responses of the 1990s produced a general consensus that, at least in some tropical rainforests in Africa, Asia, and the Pacific, hunter-gatherers lived long before the advent of agriculture. It is surprising that few of these critiques made use of archaeological or palaeoenvironmental evidence (e.g., Stearman 1991; Dwyer and Minnegal 1991; however, see Endicott and Bellwood 1991).

\section{ALTERNATIVE MODELS FROM ISLAND SOUTHEAST ASIA}

Since the development of this argument in the late 1980s and early 1990s, an increase in palaeoenvironmental and archaeological evidence from the lowland tropics (below $1000 \mathrm{~m}$ ) allows us to revisit key aspects of the debate. Building on previous work (e.g., Golson 1989; Gosden 1995; Groube 1989), Latinis (2000) argues that the colonization of inland lowland Pacific rainforests led to the development of arboreal-based subsistence economies in the late Pleistocene (including movement of forest taxa [translocation] and arboriculture; Flannery and White 1991; Yen 1998). Latinis defines arboreal-based subsistence as involving a high degree of environmental management, long-term planning, and multicropping. While tree species are often the focus, nonarboreal taxa are also extensively used and cultivated. Because of the much longer growth cycles of trees, people manage the landscape over much longer periods.

Highland tropical palaeoenvironmental data provide an interesting counterpoint to this lowland model. In general terms, palaeoecologists working in Malesia have been attuned to early evidence of disturbance and burning, however, there is little discussion of changes in vegetation that might reflect early arboriculture (e.g., Flenley 1985, 1988; Maloney 1980, 1985, and others). Beginning with Highland New Guinea in the 1970s (e.g., Golson 1977, 1989; Hope 1982), and more recently with studies by Haberle in Irian Jaya (Haberle et al. 1991; Haberle 1993, 1994), pollen and charcoal data reveal a distinctive pattern of forest disturbance in the late Pleistocene and Holocene. Both Maloney and Flenley's work in Sumatra also indicated human forest use in highland regions (greater than $950 \mathrm{~m}$ above sea level) from the beginning of the Holocene (Flenley 1985, 1988; Maloney 1980). These data are commonly interpreted as forest clearance, through burning and swidden, rather than the cultivation of tree and forest taxa (Golson 
1977; Haberle et al. 1991). Arboriculture-type adaptations, Haberle and coworkers suggest $(1991: 38)$, only begin in the highlands in the last two millennia.

\section{PREVIOUS ARCHAEOLOGICAL INTERPRETATIONS}

Southeast Asian archaeologists studying the development of food production have restricted their attention to aspects of plant domestication (origins issues) and the spread of agroecosystems (e.g., Bellwood 1997; Higham 1995, 1996; Higham and Lu 1998). Arboreal economies are rarely discussed for Mainland Southeast Asia, the general view being that only rice agriculture is significant in the development of complex societies. The conventional archaeological perspective is that agriculture was introduced to the region c. 5000-4000 B.P. by expanding agriculturalists from the central Yangzi region of China (Bellwood 1992, 1997; Higham 1995; Higham and Lu 1998). For the Malay Peninsula, archaeologists have also argued that there is a chronological and cultural gap between earlier late PleistoceneHolocene Hoabinhian hunter-gatherers and later Holocene agriculturalists (discussed below; Bellwood 1997; Endicott and Bellwood 1991), although, from the paucity of data, the extent to which the gap is in the data or in prehistoric occupations is unclear. Did hunter-gatherers leave the tropics as the humid forest developed (as Headland and Bailey might suggest)? Have we simply not identified mid-Holocene hunter-gatherer sites? Or, were there groups in the forest practicing a different set of food-production strategies?

\section{DEFINING THE PROBLEM}

If we want to assess the subsistence economy of groups in the tropics (of Peninsular Thailand) during the Holocene, several key ecological processes must be understood: (1) the timing and nature of the formation of the Holocene lowland rainforest, (2) the ecological signature of arboreal-based economies, and (3) the development of agroecosystems.

Vegetation sequences from pollen and phytoliths provide evidence for the first of these processes. Identifying arboreal-based economies, the second process, from environmental data is extremely difficult (see discussion in Latinis 2000; Courty et al. 1989), and relies upon evidence for often subtle changes in species distributions, increases in burning (in some cases), and patterns of disturbance. While still problematic, because they are as yet rare, the increasing number of microfossil sequences from both the Americas and the Old World suggest that early Holocene forest modification is widely visible (e.g., Haberle 1993, 1994; Haberle et al. 1991; Hope 1977; Hope and Golson 1995; Hope and Tulip 1994; Kealhofer 2002; Piperno and Pearsall 1998).

The third process, the development of agroecosystems, is one of the most easily identifiable in sediment sequences. Agroecosystems, by definition, are created by land-use practices including clearing, burning, and species replacement, and often cause a decrease in endemic species' abundance (Butzer 1996; Worster 1990).

Environmental data provide the means to study the wider, ecological context for long-term changes in hunter-gatherer economy and land use, and more specifically provide an independent means to assess the site-based proposition of a chronological gap in the occupation of lowland forests on the Malay Peninsula. 
Lowland tropical rainforests undoubtedly existed during Pleistocene interglacials, but to date there is little direct evidence of these forests in Mainland Southeast Asia, or of the hunters and gatherers that occupied them (cf. Anderson 1990 for one possible exception). The Holocene expansion of the tropical forest, therefore, is the first opportunity, given current evidence, to realistically assess subsistence economies in this region.

\section{THE ARCHAEOLOGY AND ITS INTERPRETATION}

Hunting and gathering adaptations have long existed in Southeast Asia. The presence of early hominids in Island Southeast Asia indicates that the earliest hunting and gathering in the region of the Malay Peninsula (Sunda) must date to at least c. 1 million years ago. However, the first direct evidence of human presence on the peninsula comes from Lang Rongrien rockshelter, dating to c. 38,000 B.P., with subsequent intermittent hunter-gatherer occupations throughout the late Pleistocene (Anderson 1990). In the early Holocene use of the Lang Rongrien rockshelter increased, either as an occupation or campsite. Along with this increase was a dramatic technological change from the earlier flake industries to a heavier core tool industry (Anderson 1990).

Much of the discussion of archaeological research on the Malay Peninsula has focused on explaining the modern distribution of ethnic groups (Bellwood 1997). Currently the Malay Peninsula is an area of great cultural diversity. Several major cultural-linguistic groups exist in the region: Semang (hunter-gatherers), Senoi (agriculturalists), Malay (Muslim, urban), and Thai (most recent immigrants). Even among Semang hunter-gatherers, subsistence behaviors seem to vary significantly (e.g., Endicott and Bellwood 1991; Rambo 1985). In explaining how this cultural diversity developed, Bellwood (1997), using both archaeological data and linguistic models, proposes a series of population expansions beginning in the Pleistocene and continuing into the last millennia.

Bellwood (1997) proposes that Hoabinhian hunter-gatherers would have expanded into the Malay Peninsula in the late Pleistocene-early Holocene, the period in which tropical rainforests were also expanding. Endicott and Bellwood (1991) further argue that these hunter-gatherers occupied inland tropical rainforests and were present in the tropical forest long before the advent of agriculture. Bellwood also postulated a gap (c. 4000-3000 B.P.) for the mid-Holocene (c. 6000-3000 B.P.) $)^{2}$ between these earlier hunter-gatherers and later agricultural expansion. While such a gap could be interpreted as a failure of their adaptation in the face of climax lowland tropical forests (cf. Headland and Reid 1989), the paucity of supporting data for this scenario, and the rarity of radiocarbon dates, raise basic questions about the adequacy of the evidence. How did groups in the early Holocene make a living? Did hunter-gatherers in tropical Malaysian forests live independently of agriculturalists? Is the chronological and cultural gap real or a lacuna in the archaeological data? Is the distinction between agriculture and hunting and gathering as clear as Bellwood and others suggest (cf. Hutterer 1983)? Answers to these questions are related to how the Hoabinhian is interpreted and whether it reflects hunter-gatherers or horticulturalists.

While the Hoabinhian is a problematic category, the earliest assemblages with Hoabinhian technology are c. 13,000 years old on the Malay Peninsula. No 
Hoabinhian sites have been identified with occupation levels dating as early as the Last Glacial Maxima (LGM, 18,000 B.P.) (Bellwood 1997:160). If the Hoabinhian is a Southeast Asian cultural development, its late occurrence in the Malay Peninsula may denote a population expansion into the area (Bellwood 1997:161). Most Hoabinhian sites on the peninsula, like Lang Rongrien, date to the early to mid-Holocene (through 3000 B.P.). The best-known Malay sites are in inland caves, such as Gua Cha (Adi 1985; Sieveking 1954). Several sites from the region of the study area (Khao Khanab Nam, Na Ching, and Tham Phi Huato) may date to 5000-6000 в.P.; these include pottery as well as ground stone axes and adzes. The subsistence base for these sites is unknown.

Following the Hoabinhian, Bellwood (1997:255) proposes a rapid Neolithic expansion or colonization of the peninsula after 4000 B.P. from Ban Kao agricultural communities directly to the north in central and western Thailand. Archaeologically, there is a shift in site usage; cave sites previously used as huntergatherer camp or occupation sites become burial sites during the "Neolithic" period. Based on evidence from these sites, he argues that there is a gap in inland Malay archaeological sites between Hoabinhian and ancestral Senoi-agricultural occupations (Bellwood 1997:165, 268).

Rapid Neolithic colonization is followed less than 1000 years later by a slower Austronesian expansion from the opposite direction: the islands to the east. Slightly later, during the period from 2500-1500 B.P., groups initiated revolutionary changes in material culture, including metalworking (bronze and iron) (Bellwood 1997:286-287; Sieveking 1956). Evidence from Kuala Selinsing suggests a subsistence economy that was extremely diverse, with domesticated pigs, dogs, and chickens, as well as hunting, and a wide range of domesticated plants, including rice, coconut, gourds, bamboo, and Areca nut (Davison 1991; Nik Hassan Shuhaimi 1991).

The discontinuities in the archaeological data over the course of the Holocene have thus been interpreted as the result of external influences, particularly migration, in the Malay Peninsula. While more intensive regional archaeological survey can undoubtedly provide one means to assess these hypotheses, environmental sequences that contribute evidence of human land use can also be used to assess changes in cultural subsistence practices and discontinuities in occupation.

\section{PREVIOUS ENVIRONMENTAL RESEARCH IN THE REGION}

While archaeological data are few, environmental data for the late Pleistocene and early Holocene of the Malay Peninsula are even fewer. Until the Thailand Paleoenvironmental Project (TPP) study, the limited palaeovegetational evidence available for the Malay Peninsula was all from the mid-Holocene and later (see Maloney 1992). Only three dated pollen sequences exist for the region (less than 5000 years old): two from the east side of the peninsular divide (Allen 19881989; Hastings 1983; Thanikaimoni 1983), and one from Tasek Bera, in the southern Malay Peninsula (Morley 1981). The focus of research has been on sealevel changes and mangrove dynamics (e.g., Hillen 1984; Tjia 1996). The Tasek Bera sequence is one of the few to reveal a dry-land vegetation sequence, with a lowland evergreen forest (Dipterocarpaceae, Euphorbiaceae, Garcina spp., and Fagaceae species among others; Morley 1981). Two other areas of the southern 
peninsula have been studied, but not dated (Haseldonckx 1977; Hillen 1984). Further afield, several sequences have been studied from central Thailand; the best documented are the cores from around Khok Phanom Di (Kealhofer and Piperno 1996; Maloney 1991).

Sea-level changes are more widely studied (Tjia 1996). The maximum transgression, 6000-4800 B.P., was about $4 \mathrm{~m}$ higher than present. Relative sea levels have declined episodically since that time. None of these data, however, provides us with an accurate picture of late Pleistocene and early Holocene environments on the Malay Peninsula.

A general picture of regional environmental changes comes from sequences taken outside of the area (e.g., Jiang and Piperno 1999; Kealhofer and Penny 1998; Liu et al. 1992; Maxwell and Liu 1996; Maxwell 2001; Penny 2001; Prell et al. 1980; Ren 1984; Sun and Chen 1991; Verstappen 1975, 1980; Zhao and Piperno 2000; Zheng and Li 1999). Pleistocene evidence from adjacent areas, such as the South China Sea (Chang 1984), the Indian Ocean (Prell et al. 1980; Verstappen 1975, 1980), Island Southeast Asia (Maloney 1992), and southern China (Liu et al. 1992), provides a general context for understanding local Pleistocene change. Overall the climate during the Last Glacial Maximum on the Malay Peninsula is thought to have been measurably cooler and drier than at present, with a more open savanna forest (see summary in Anderson 1990:73). During the Pleistocene, most of the Sunda shelf, on which the peninsula rests, was dry land. This broad area was rapidly inundated with sea level rises in the early Holocene. The lower sea levels of the Last Glacial Maximum would have had a substantial effect on climate, including wind and rainfall patterns. Rainfall from the northeastern monsoons, given the diminished source of seawater, would have been much less. This would have increased seasonality, particularly in rainfall, but also in temperature.

More recently, long-term sequences from inland Southeast Asian contexts support this general interpretation (although the timing of climatic change is still in question). The focus of this research, however, has been on the timing of the Holocene monsoon maxima (Hodell 1999; Maxwell and Liu 1996; Maxwell 2001), the spatial patterning of the LGM and the nature of the Pleistocene-Holocene transition (Penny 2001; Steinke and Kienast 2001). Discussion of human land use has been limited (Kealhofer 1997, 2002; Kealhofer and Penny 1998; Kealhofer and Piperno 1994, 1996). What these sequences and more general discussions of Pacific-Asian climatic change reveal is that climate and environmental change is significantly variable, in particular when the Holocene monsoon maximum occurred, along with related changes in temperature and precipitation. This intraregional variability further emphasizes the importance of more systematic and intensive sampling of environmental data throughout Southeast Asia.

In summary, while coarse-grained sequences of climate and vegetation change exist for the subtropical portions of Mainland Southeast Asia and adjacent areas (and more detailed evidence from Island Southeast Asia), the Pleistocene and early Holocene climate and vegetation for the Malay Peninsula has not been studied. Given the regional variability in timing and content, these data are critical for interpreting both human adaptation to the changing landscape and the biogeography of the region. The TPP sampled sediments from one of the inland 


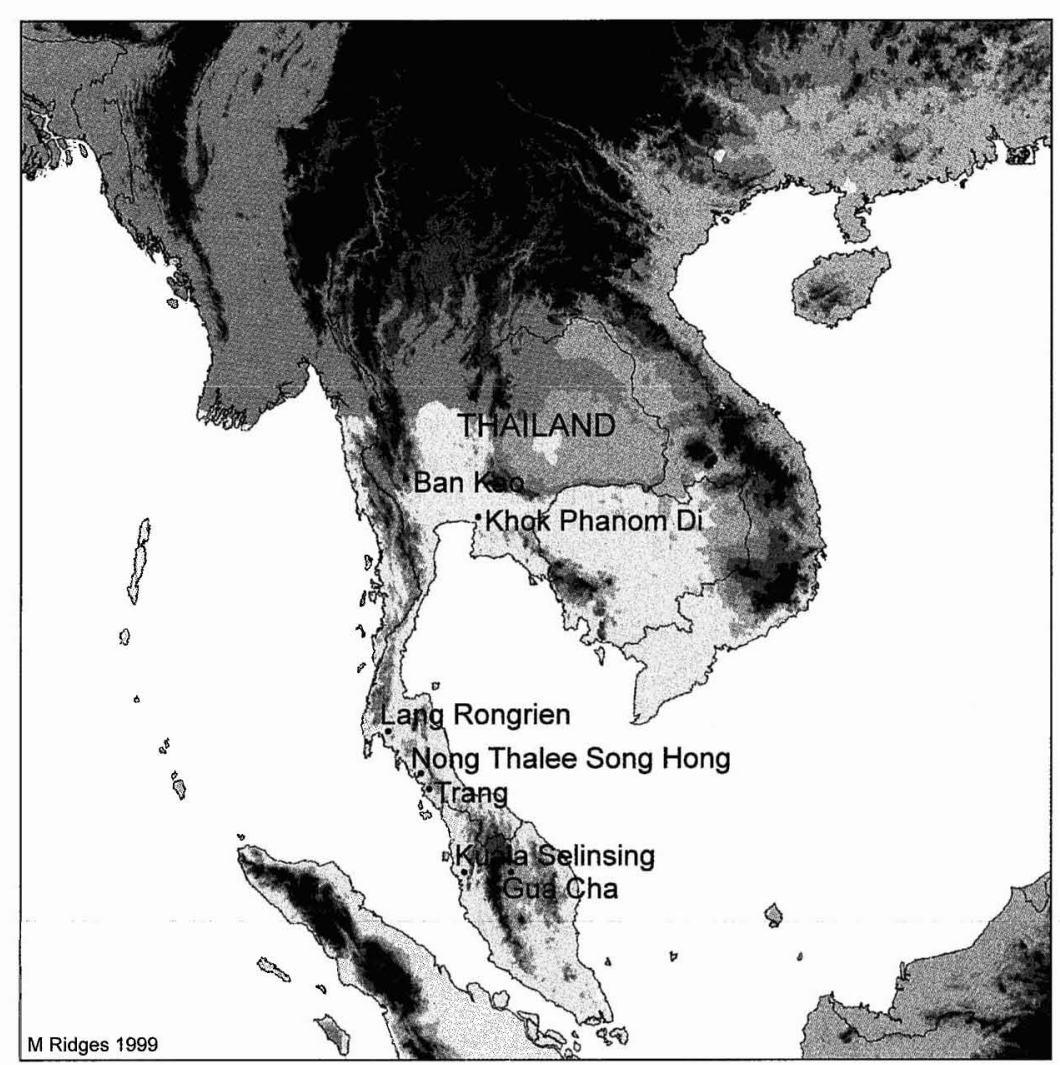

Fig. 1. Topographic map of Southeast Asia with the sites of interest indicated.

lakes in the Thai portion of Malay Peninsula in order to provide a first look at the long-term environmental history of this region.

\section{ENVIRONMENTAL CONTEXT}

The palaeoenvironmental evidence discussed here comes from a small lake, Nong Thalee Song Hong, in southern, peninsular Thailand (at $7^{\circ} 50^{\prime} 56^{\prime \prime} \mathrm{N}, 99^{\circ} 28^{\prime} 48^{\prime \prime} \mathrm{E}$, north of Trang; Fig. 1). Sediment cores were taken from the deepest part of this shallow bilobate lake. Lake elevation is approximately $100 \mathrm{~m}$, with adjacent hills ranging from $200-400 \mathrm{~m}$. The lake is currently located inland from the coast and during the late Pleistocene was even further inland, as sea levels were locally at least $100 \mathrm{~m}$, and possibly 120-150 m lower (cf. Anderson 1990; Chappell and Thom 1977; Tjia 1994, 1996; Zheng and Li 1999). While some of the Malay Peninsula is dominated by karstic formations, making it difficult to impossible to study microbotanical remains ${ }^{3}$ the geology of the area is sedimentary and metamorphic. The soils derive from a variety of shales and sandstones rather than limestone, making palaeovegetation studies possible (Somboon pers. comm. 1996; Young 1976). 
The present climate in the region has mean annual temperatures ranging between 26 and $8{ }^{\circ} \mathrm{C}$ and a mean annual relative humidity above 80 percent (Donner 1978). Rain falls throughout the year, although a short dry season occurs between January and March. Most rain falls in summer, from the southwest monsoon. Trang, the nearest city, had a mean annual precipitation of $2178 \mathrm{~mm}$ from 1931-1960 (Donner 1978).

Today, rubber plantations introduced in 1901 have replaced much of the tropical forest of southern Thailand. Rice is the second largest crop in the province, in terms of area, followed by coconuts, maize, cassava, and peanuts. Perennial fruit trees are grown on upland soils, in gardens or in farmyards (oranges, rambutan, limes, and mangoes). Areca palms and Ceiba pentandra (kapok) trees are also common.

The natural vegetation of the area prior to commercial development likely included lowland tropical rainforest, dominated by Dipterocarpaceae species (Boulbet 1995; Donner 1978; Smitinand 1976). In the remaining forested areas, Lauraceae, Myrtaceae, and Annonaceae species are generally predominant in the lower canopy, and Acanthaceae and Rubiaceae are undergrowth shrubs. Palms, canes, and other monocotyledons are common, but bamboos other than climbing forms are rare. Ogawa and colleagues (1965) documented secondary forest in the region as including Myrtaceae, Apocynaceae, legumes (Millettia), and Sterculiaceae (Eugenia clarkeana, Alstonia spathulata, Padbruggea pubescens, Sterculia spp.). Euphorbiaceae are one of the most common tree families in lowland forest, with genera like Endospermum, Macaranga, Mallotus, and Sapium abundant to common in secondary growth forests (Maloney 1999; Whitmore 1973).

\section{METHODOLOGY}

As a first assessment of the viability and potential of lowland tropical lakes in southern Thailand for palaeoenvironmental study we analyzed one sequence from Lake Thalee Song Hong. Both pollen (Maloney 1999) and phytoliths were extracted from this core, although only phytoliths are preserved in the Pleistocene section of the sequence. Processing and analysis followed standardized techniques making use of regionally specific reference collections (Kealhofer and Piperno 1998). Microfossil preservation from the early Holocene is exceptional, and concentrations of pollen, spores, phytoliths, and starch grains are high. Carbon isotope samples were also analyzed through the sequence as another measure of the nature of vegetation change. Dates for the sequence are presented in Table 1.

Table i. AMS Dates from Nong Thalee Song Hong, Trang

\begin{tabular}{lcccc}
\hline & $\begin{array}{l}\text { ABSOlUte DEPTH } \\
\text { LAB NO. }\end{array}$ & $\begin{array}{l}\text { RADIOCARBON AGE B.P. } \\
\text { (UNCALIBRATED) }\end{array}$ & \multicolumn{1}{c}{$\begin{array}{l}\text { SEDIMENTATION RATE } \\
\text { (CM/YR) }\end{array}$} \\
\hline Beta-106539 & $84-90$ & $6330 \pm 50$ & -26.0 & 0.014 \\
Beta-106537 & $148-158$ & $10820 \pm 50$ & -25.4 & 0.015 \\
Beta-106538 & $267-272$ & $21170 \pm 90$ & -22.3 & 0.007 \\
\hline
\end{tabular}


Phytoliths, like pollen, provide information about past vegetation (Pearsall 2000; Piperno 1988). Unlike pollen, phytoliths are produced in different parts of plants (not just the flower), and are most common in monocotyledons (grasses, palms, sedges, gingers, etc.). Because they are made of hydrated silica, phytoliths often preserve better than pollen, and can withstand dry conditions. Phytoliths are specifically applicable to studies of disturbance vegetation, since they are diagnostically specific for many weedy species that are not differentiable in pollen assemblages (e.g., Kealhofer and Piperno 1994; Piperno and Pearsall 1998).

Phytoliths are also often particularly useful for identifying evidence of burning in the landscape (for further discussion of burning regimes, see Kealhofer 2002). Not only are carbonized particles preserved in some instances, as in pollen preparations, but also the phytoliths or silica bodies themselves often show burning (through blackening and melting). Because one can taxonomically differentiate which phytoliths are burned and which are not, an analyst can often distinguish grass burning from tree burning (cool burns from hot burns). Patterning of burning through time can also be related to fire ecologies or land use (e.g. Grave and Kealhofer 1999; Kealhofer 1996b).

Phytolith percentages are presented in Table 2, based on sample counts of 200 phytoliths per sample. These percentages are graphically summarized in Figure 2.

\section{RESULTS: THE ENVIRONMENT OF THE MALAY PENINSULA}

\section{Late Pleistocene}

The Lake Thalee Song Hong core provides our first direct evidence that the Pleistocene forests of this tropical region were mosaics of savanna/woodlands (Table 1). The Pleistocene phytolith samples include abundant Panicoideae grasses and relatively few trees (Fig. 3). Other taxa and the lack of preserved pollen suggest a seasonally dry lake basin. Burning was common during the late Pleistocene, as would be typical of a seasonal grassland/forest mosaic. The forest was fairly diverse with a range of Dipterocarpaceae, Moraceae, Ulmaceae, and Euphorbiaceae phytolith types. Interestingly, the maximum forest contraction dates to the eleventh millennium B.P. rather than the Last Glacial Maximum (18,000 в.P.), suggesting local dynamics at odds with global climatic patterns or hunter-gatherer resource management. The limited chronological resolution makes it difficult to differentiate these.

\section{The Early Holocene}

By the early Holocene the vegetation changed dramatically. In general, as might be expected with rising sea levels and water tables, the forest expanded (arboreal group, Fig. 3). However, several anomalies are present. The most substantial evidence of disturbance and burning is in the early Holocene and after 6500 B.P. Both in the phytolith and in the pollen data, the high percentage of disturbance taxa (SRS [small rough spheres] in Figure 3, ${ }^{4}$ but also grasses from subfamilies such as Chloridoideae and Bambusoideae) and low-level evidence for burning, both of wood and of grasses (Fig. 4), continue throughout the Holocene (see also Maloney 1999). 
From the mid-seventh millennium B.P. evidence for disturbance increases, arboreal taxa change (Figs. 2, 5: MFP, VarSpheres), and economic plants appear. Disturbance, however, is apparently small scale, in the form of 'gaps' in the forest canopy filled with second growth forest taxa. Grasses virtually disappear from the sequence: very little sunlight was reaching the forest floor.

At the same time economic plants appear in the sequence. As is typical in environmental sequences even in agricultural regions, economic plant indicators are present in low frequencies (cf. Piperno and Pearsall 1998). These economic plant phytoliths include a few palm types within the smaller size range of economic coconut species, Areca and Cocos, and bananas (Musa sp.; 5000 в.P.) c. 5000-6000 B.P. Rice phytoliths are present in very low numbers up until c. 4800 B.P. These rice phytoliths are a different species from the early Holocene (wild) rice taxa, and may include domesticated rice (Oryza sativa). Morphologically they fall within the O. rufipogon-sativa subgroup (Kealhofer n.d.). Other, undiagnostic arboreal types mirror this complexity, with a variety of new forms appearing and disappearing throughout the section (Fig. 5).

Burning intensifies in two phases, with grass burns increasing c. 3500 B.P. and a major peak in burned wood c. 2700 B.P. Dipterocarpaceae (the dominant forest trees) expansion is in fact at its greatest in the first millennium A.D., when historical evidence suggests expanding exchange networks and agricultural intensification in adjacent areas (Bellwood 1993, 1997; Donner 1978). At the same time, diversity among trees and shrubs decreases (Fig. 5).

\section{The Pollen Data}

Maloney (1999) provides summary pollen data for the Nong Thalee Song Hong core. Pollen was only preserved in the sediments of the last 10,000 years, limiting his discussion to the Holocene. The charcoal record in the pollen data demonstrates a strong fire record throughout the Holocene (Maloney 1999:210). Two general stories can be derived from the pollen data: evidence for forest disturbance and evidence for the cultivation of economic species (particularly arboreal taxa). For forest disturbance, two genera in particular are related to regrowth, often following anthropogenic disturbance: Macaranga and Mallotus. These taxa show up in significant frequencies in all but two samples from the core (c. 10,650 and 8600 в.P.). In addition, during the early Holocene (9600-8300 в.Р.) and later mid-Holocene (c. 5500-4800 B.P.) several weeds associated with cultivation are present. For economic species, Areca (palm species ethnographically used with betel nut) first occurs at c. 10,300 B.P. and is more common from 6600-4000 B.P., as is Caryota (sugar palm). After 4000 B.P. there are significant changes in the record (major expansion of Dipterocarpaceae pollen), including the appearance of additional economic taxa, such as possible Piper (pepper), Artocarpus, and Garcinia (Maloney 1999:213). Interestingly, Maloney notes the intermixed presence of forest trees and economic tree taxa, with intentional conservation of large trees, indirectly supporting the idea of arboriculture. Maloney concludes (1999:214, 216) that the vegetation was never stable in this small lake catchment, with evidence of both forest destruction and possible horticulture predating the midHolocene. 
Table 2. Phytolith Percentages from Nong Thalee Song Hong

DEPTH OF CORE (IN CM)

\section{Poaceae}

Bambusoideae

Saddle

Wide saddle

T2pt Bilobate

T4pt Bilobate

2pt Bilobe

Oryza glume cells

Oryza bilobate

Other Poaceae

$\mathrm{C}-\mathrm{c}$

Tall C-c

$2 p t C$

$\mathrm{O}-\mathrm{O}$

Panicoideae

Bilobate

Line bilobe

Cross

2-cell hair

3/2 lobate

Irregular lobate

Clover

Trilobe

Tall narrow bilobate

Chloridoideae

Squat saddle

Cyperaceae

Sedge achenes

Small Rough Sphere

$\begin{array}{rrrrrrrr}0 & 0 & 0 & 1 & 0 & 4 & 8 & 4 \\ 0 & 0 & 0 & 0 & 0 & 0 & 0 & 0 \\ 0 & 0 & 0 & 0 & 0 & 0 & 0 & 0 \\ 0 & 0 & 0 & 0 & 0 & 0 & 0 & 0 \\ 0 & 0 & 0 & 0 & 0 & 0 & 0 & 0 \\ 0 & 0 & 0 & 1 & 0 & 0 & 0 & 1 \\ 0 & 0 & 0 & 0 & 0 & 1 & 1 & 1 \\ 0 & 0 & 0 & 0 & 1 & 1 & 1 & 0 \\ 0 & 0 & 0 & 0 & 0 & 1 & 2 & 0 \\ 0 & 0 & 0 & 0 & 0 & 0 & 1 & 0 \\ 0 & 0 & 0 & 0 & 0 & 0 & 0 & 1 \\ 0 & 1 & 0 & 2 & 7 & 5 & 13 & 12 \\ 0 & 0 & 0 & 0 & 0 & 0 & 1 & 0 \\ 0 & 0 & 0 & 1 & 0 & 2 & 2 & 3 \\ 0 & 0 & 0 & 1 & 0 & 1 & 2 & 2 \\ 0 & 0 & 0 & 0 & 1 & 0 & 0 & 0 \\ 0 & 0 & 0 & 0 & 0 & 0 & 0 & 0 \\ 0 & 0 & 0 & 0 & 0 & 1 & 0 & 0 \\ 0 & 0 & 0 & 0 & 0 & 0 & 1 & 0 \\ 0 & 0 & 0 & 0 & 0 & 0 & 0 & 0 \\ 0 & & & & & & & \\ 0 & 0 & 0 & 0 & 0 & 1 & 2 & 1 \\ 0 & 0 & 0 & 1 & 1 & 0 & 0 & 1 \\ 0 & 26 & 14 & 13 & 7 & 14 & 20\end{array}$

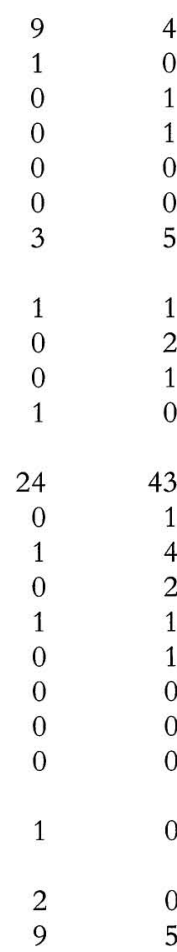

$\begin{array}{rrr}4 & 8 & 4 \\ 0 & 0 & 0 \\ 0 & 0 & 0 \\ 0 & 0 & 0 \\ 0 & 0 & 0 \\ 0 & 0 & 0 \\ 1 & 3 & 0 \\ 0 & 1 & 1 \\ 1 & 1 & 1 \\ 0 & 0 & 1 \\ 0 & 0 & 0 \\ & & \\ 35 & 26 & 28 \\ 0 & 0 & 0 \\ 2 & 1 & 0 \\ 1 & 1 & 2 \\ 0 & 1 & 0 \\ 0 & 0 & 0 \\ 0 & 0 & 0 \\ 1 & 0 & 0 \\ 0 & 0 & 1 \\ & & \\ 2 & 1 & 2 \\ 0 & & \\ 9 & 12 & 12\end{array}$




\begin{tabular}{|c|c|c|c|c|c|c|c|c|c|c|c|c|c|}
\hline \multicolumn{14}{|l|}{ Araceae } \\
\hline Palm & 5 & 4 & 7 & 7 & 6 & 6 & 2 & 4 & 7 & 4 & 7 & 7 & 0 \\
\hline Caryota & 0 & 0 & 0 & 0 & 0 & 1 & 0 & 0 & 1 & 0 & 0 & 0 & 0 \\
\hline \multicolumn{14}{|l|}{ Musaceae } \\
\hline Musa & 0 & 0 & 0 & 1 & 0 & 0 & 0 & 0 & 0 & 0 & 0 & 0 & 0 \\
\hline \multicolumn{14}{|l|}{ Arboreal } \\
\hline Sclereid & 1 & 2 & 1 & 6 & 7 & 5 & 4 & 5 & 5 & 9 & 7 & 2 & 6 \\
\hline Smooth sphere & 23 & 18 & 26 & 16 & 24 & 25 & 15 & 16 & 14 & 5 & 4 & 8 & 10 \\
\hline Small irregular smooth sphere & 0 & 0 & 0 & 0 & 0 & 0 & 0 & 0 & 0 & 0 & 1 & 0 & 0 \\
\hline Knobbed sphere & 0 & 0 & 0 & 0 & 0 & 0 & 0 & 0 & 0 & 0 & 1 & 0 & 0 \\
\hline Large rough sphere & 35 & 32 & 32 & 20 & 21 & 18 & 14 & 18 & 8 & 6 & 7 & 10 & 7 \\
\hline Tabular sphere & 0 & 1 & 1 & 2 & 1 & 0 & 0 & 0 & 0 & 0 & 0 & 0 & 0 \\
\hline MFP & 1 & 1 & 0 & 2 & 1 & 0 & 2 & 1 & 1 & 0 & 0 & 0 & 0 \\
\hline Small MFP & 0 & 0 & 0 & 0 & 0 & 0 & 0 & 0 & 0 & 0 & 1 & 0 & 0 \\
\hline Cystolith & 2 & 6 & 2 & 8 & 4 & 9 & 5 & 4 & 4 & 5 & 4 & 3 & 3 \\
\hline Elongate MFP & 2 & 0 & 0 & 2 & 0 & 2 & 0 & 1 & 1 & 0 & 0 & 0 & 0 \\
\hline Spherical MFP & 0 & 0 & 0 & 1 & 0 & 0 & 0 & 0 & 0 & 0 & 0 & 0 & 0 \\
\hline Irregular concave MFP & 0 & 0 & 0 & 0 & 0 & 9 & 0 & 0 & 1 & 0 & 0 & 0 & 0 \\
\hline \multicolumn{14}{|l|}{ Unidentified Forms (mostly } \\
\hline $\begin{array}{l}\text { UNID1: sinuous bulbous } \\
\text { spiculate elongate }\end{array}$ & 0 & 3 & 0 & 0 & 0 & 0 & 0 & 0 & 0 & 0 & 0 & 0 & 0 \\
\hline UNID4: smooth irregular globule & 0 & 0 & 0 & 0 & 11 & 0 & 8 & 3 & 1 & 0 & 0 & 0 & 0 \\
\hline UNID5: Marantaceae-type & 0 & 0 & 0 & 0 & 1 & 0 & 0 & 1 & 3 & 3 & 3 & 4 & 0 \\
\hline UNID6: large ovoid (50 mu) & 4 & 2 & 0 & 0 & 0 & 0 & 0 & 0 & 0 & 0 & 0 & 0 & 3 \\
\hline UNID8: bumpy spheroid & 0 & 0 & 0 & 3 & 0 & 0 & 0 & 0 & 0 & 0 & 0 & 0 & 0 \\
\hline UNID9: bulbous sphere/ovoid & 0 & 0 & 0 & 9 & 0 & 0 & 0 & 0 & 0 & 1 & 0 & 1 & 0 \\
\hline UNID10: smooth tubular & 0 & 0 & 0 & 5 & 0 & 1 & 0 & 0 & 0 & 0 & 0 & 0 & 0 \\
\hline UNID11: linked spheres & 0 & 0 & 0 & 0 & 1 & 2 & 2 & 0 & 0 & 0 & 0 & 1 & 0 \\
\hline UNID12: spiculate globule & 0 & 0 & 0 & 0 & 2 & 1 & 0 & 0 & 0 & 0 & 0 & 1 & 0 \\
\hline UNID13: carapace & 0 & 0 & 0 & 0 & 2 & 1 & 0 & 0 & 1 & 0 & 0 & 1 & 0 \\
\hline UNID14: dimpled sphere & 0 & 0 & 0 & 0 & 0 & 1 & 0 & 1 & 0 & 0 & 0 & 0 & 0 \\
\hline UNID15: spongy globule & 0 & 0 & 0 & 0 & 0 & 0 & 0 & 2 & 0 & 0 & 0 & 0 & 0 \\
\hline UNID18: large faceted ovoid & 1 & 0 & 0 & 0 & 0 & 0 & 0 & 0 & 0 & 0 & 0 & 0 & 0 \\
\hline UNID19: spindly spheroid & 0 & 0 & 0 & 0 & 0 & 0 & 0 & 0 & 0 & 0 & 0 & 4 & 13 \\
\hline UNIDS & 0 & 0 & 2 & 2 & 2 & 4 & 5 & 2 & 4 & 2 & 2 & 2 & 7 \\
\hline
\end{tabular}




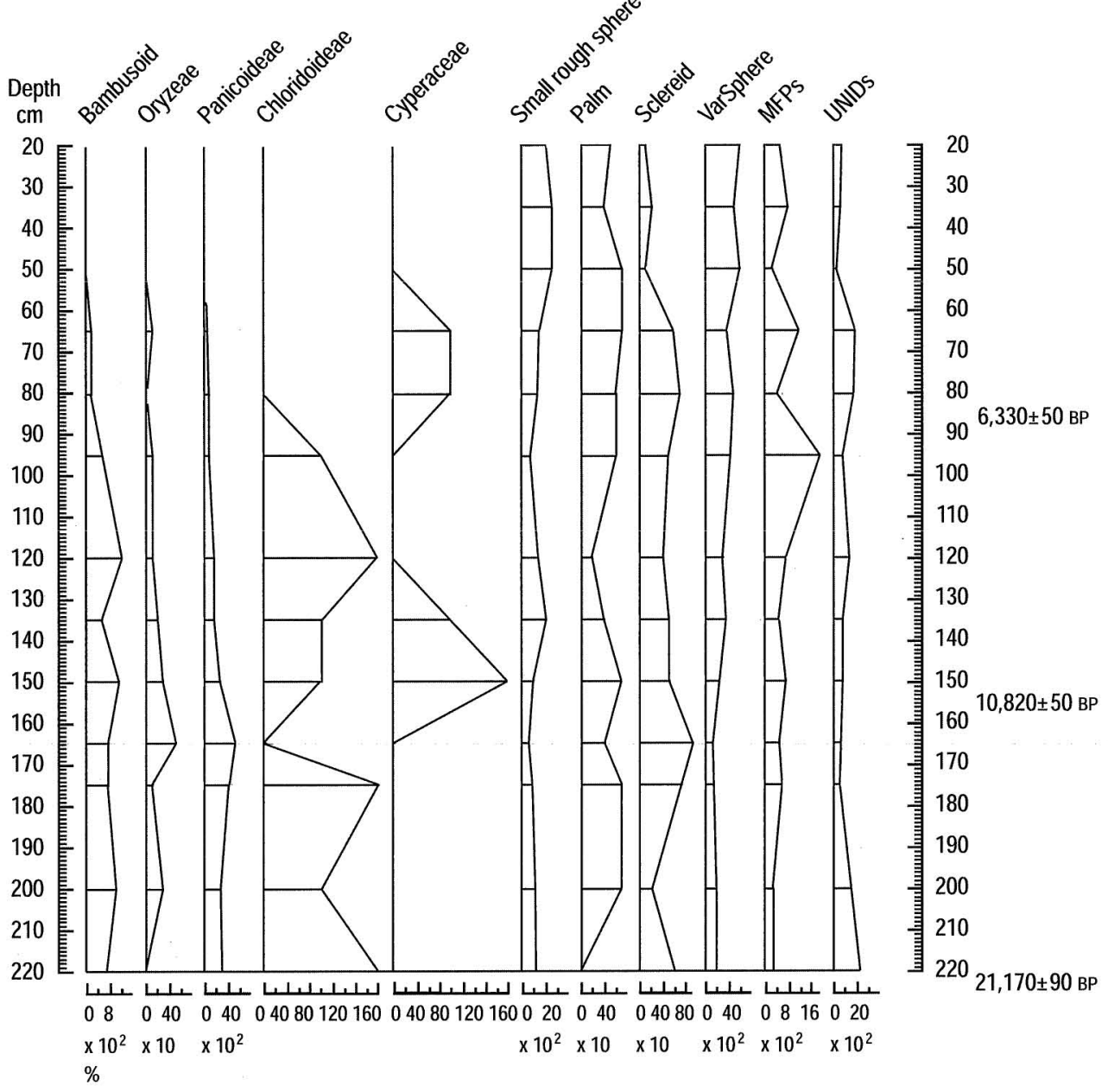

Fig. 2. Nong Thalee Song Hong summary phytolith diagram (expressed in relative percentage). Grass subfamilies and tribes: Bambusoideae, Oryzeae, Panicoideae, Chloridoideae. Sedges: Cyperaceae. Arboreal indicators: Small rough spheres (Euphorbiaceae?), Palms, Sclereids, VarSpheres (other sphere types), MFPs (multifaceted polyhedral forms), UNID (dicotyledon and arboreal forms).

The pollen and phytolith data together provide a coherent and complementary picture of Holocene vegetation change (cf. Maloney 1999). The pattern and timing of disturbance is the same for both pollen and phytoliths. Secondary regrowth taxa are found throughout the Holocene, with peaks in intensity in the middle Holocene, c. $6000-5500$ B.P., and from 4000-3500 B.P. to present.

\section{DISCUSSION}

Several patterns are clear in this sequence. At c. 20,000 B.P., there is no evidence of lowland tropical rainforest. The landscape was composed of a mosaic of sa- 


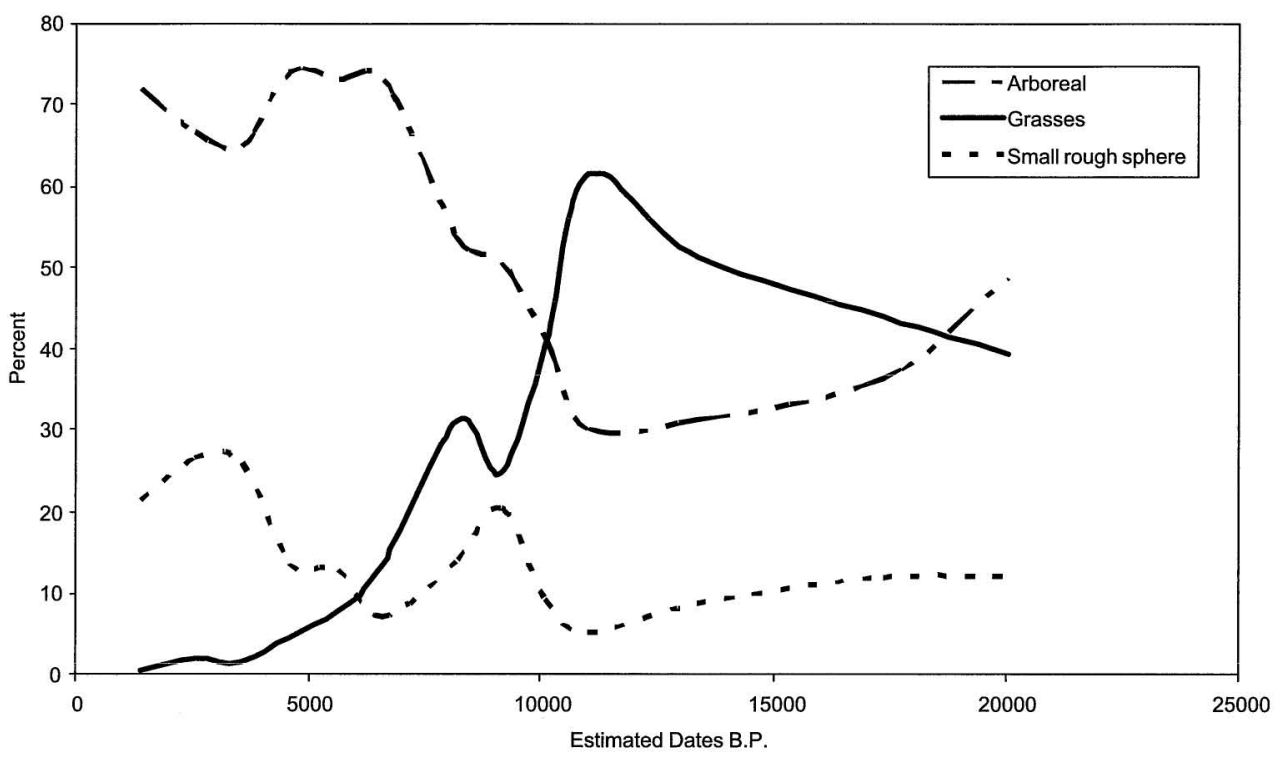

Fig. 3. The relative percentage of selected phytolith groups over time showing the changing pattern of grasses, disturbance indicators, and trees. Graph shows an increase in disturbance indicators during the Holocene and a decline in grasses.

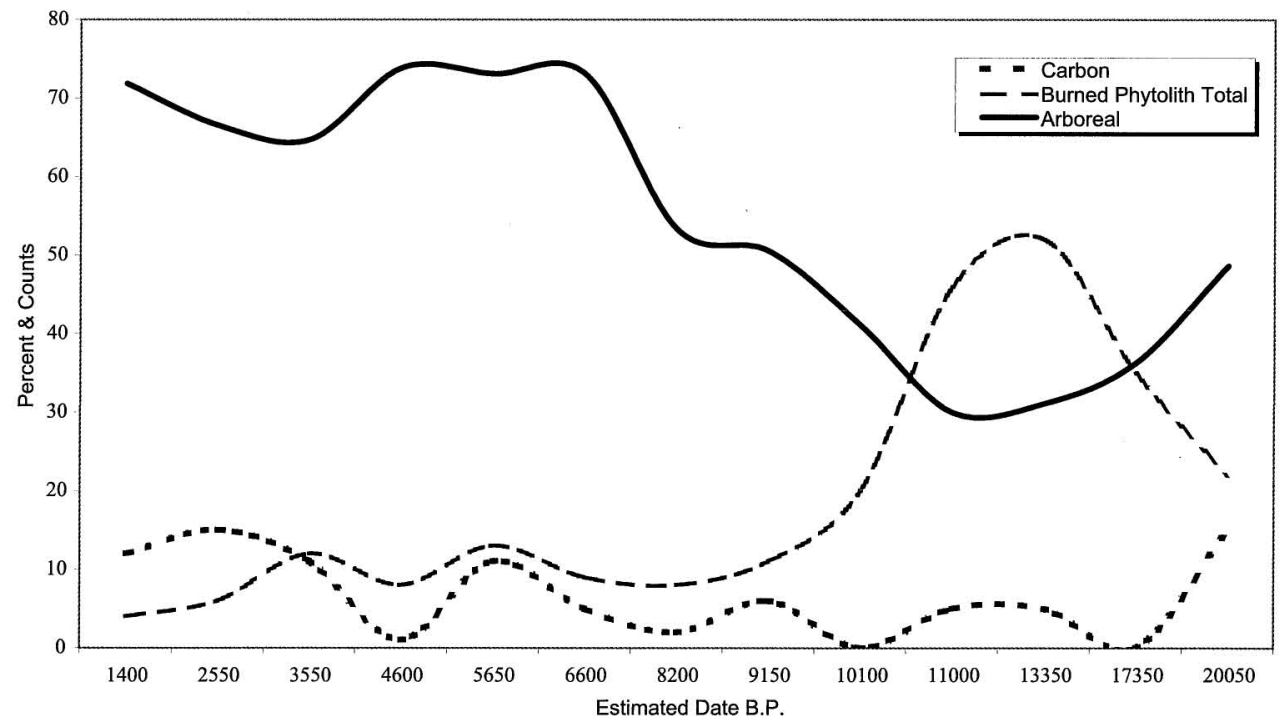

Fig. 4. Evidence related to burning over time showing the pattern of burning revealed in burned phytoliths and carbonized particles (different signatures) relative to the overall tree assemblage. The graph shows a decrease of burning in grasses from the Pleistocene to the Holocene but continued burning is seen in the presence of carbonized particles and phytoliths throughout the Holocene. 


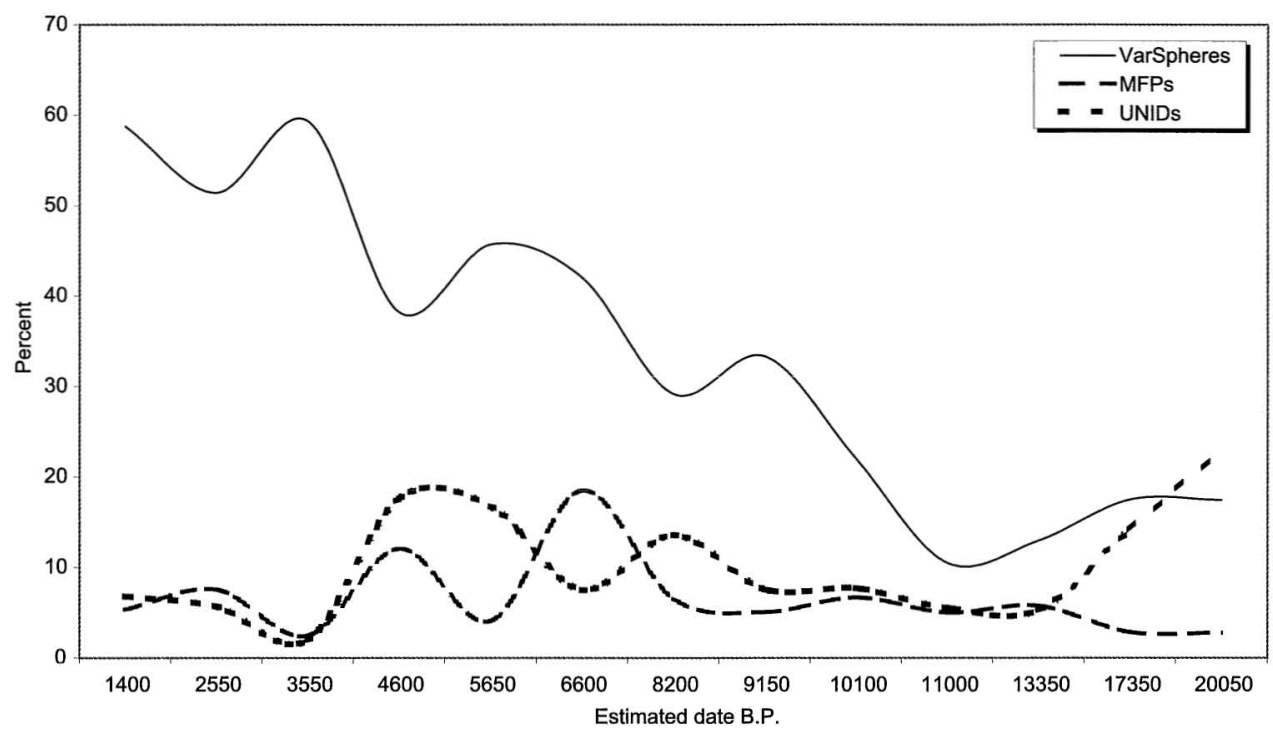

Fig. 5. Arboreal indicators (both economic and forest). The graph shows evidence of forest expansion beginning in the early Holocene, with a sharp decrease in arboreal diversity after ca. 4,500 B.P.

vanna and woodland, with open areas increasing through the LGM. As in areas considerably further north (Kealhofer 1996a; Kealhofer and Penny 1998; Penny 2001), burning was common in this savanna/woodland landscape. The extent to which this burning was natural vs. cultural is unclear. Natural savanna/woodland (or seasonal tropical forest) fire regimes are not well documented, but burning is probably somewhat less common than in the better-documented chaparral where fires occur every 20-30 years (DeBano et al. 1998:201; Kauffman and Uhl 1990). The fire record (from burned phytoliths and silica in the phytolith samples) indicates frequent low-intensity fires, more suggestive of regular managed burns. Obviously, arguments about hunter-gatherers in the forest are not relevant in this relatively open environment (and elsewhere in Island Southeast Asia as others have noted, Endicott and Bellwood 1991).

The formation of lowland rainforest is first apparent in the sequence from 11,000-9000 в.P.. The sequence provides evidence of ongoing burning and disturbance at the same time that tropical rainforest expands to its Holocene maximum. This pattern is unlikely to be a natural phenomenon (Fig. 4). Studies of fire regimes in tropical rainforests suggest that natural fires occur once every 3901500 years (DeBano et al. 1998:201; Kauffman and Uhl 1990), and that long return fires may be correlated with El Niño or ENSO (El Niño Southern Oscillation) related events and drought (Goldammer and Seibert 1990). The higher frequency of fires in this sequence suggests that local groups may have worked to create or maintain open patches as the forest canopy closed. As landscape ecologists note, greater biodiversity is created with managed low levels of disturbance (Farina 1998; Forman 1995). In tropical forests this diversity would have made economically useful plants more abundant and accessible. The increased arboreal diversity between ca. 8,000-4,000 B.P. (Fig. 5) supports an interpretation of forest management. 
Evidence of intensifying or diversifying land use appears in the phytolith record by the mid-seventh millennium B.P., and continues episodically until the present. The presence of economic species in the pollen sequence at this time supports this as well. This does not look like grain-based agriculture, as grasses virtually disappeared from the sequence. Rather, the increase in diversity appears to relate to a combination of intentional (cultivation) and unintentional human disturbance factors. Throughout the Holocene, the high percentage of disturbance taxa (SRS [small rough spheres] and some grass phytoliths, Mallotus and Macaranga pollen) and the continuing low-level evidence for burning (in both the pollen and phytolith sequences) of both wood and grasses, indicates that here, as elsewhere in Thailand, human land use shaped the local ecology (Kealhofer 1996a, 1996b, 2002; Kealhofer and Penny 1998; Kealhofer and Piperno 1994; Maloney 1999).

Contemporary with the expansion of Holocene forests, archaeologists have documented a shift in lithic technology during the late Pleistocene-early Holocene (e.g., Anderson 1990; Gorman 1971). This shift is apparent in early Holocene deposits at the nearby site of Lang Rongrien. The shift from flake assemblages to heavier core woodworking-type tools provides a measure of how much technological adaptation was required to accommodate the substantial changes in resource distribution and abundance as the rainforest spread.

How these changes relate to the beginnings of food production, distinct from the irreversible changes of agriculture (i.e., agroecosystem, Butzer 1996; Hutterer 1983; Worster 1990), cannot yet be defined. More sequences and more detailed analyses are needed. However, one can speculate on the most likely form of early food production given the environmental data presented here. As discussed above, in other parts of Southeast Asia early food production has been suggested to be based on an arboreal economy (Gosden 1995; Latinis 2000). Latinis $(2000: 56)$ summarized discussions of arboreal-based economies in Island Southeast Asia: "The evidence ... thus far ... suggests that incipient arboreal based economies developed in the Late Pleistocene in the region encompassing Near Oceania, New Guinea and Wallacea."

Environmental evidence from both Sumatra and New Guinea reveal rainforest disturbance by the ninth millennium B.P. (increase in pioneering Macaranga), possibly related to human activities (Flenley 1988; Newsome and Flenley 1988).

This accumulated evidence highlights the frequently noted problem with categorizing subsistence behavior (Golson 1989; Gosden 1995; Harlan 1992; Harris 1989; Hutterer 1983). While definitions of "agriculture" vary-from solely seedbased to more taxonomically inclusive (e.g., Golson 1989; Gosden 1995; Harris 1989, 1996; Price and Gebauer 1995) — these environmental and archaeological data suggest that groups in early Holocene tropical rainforests may have tailored arboriculture, horticulture, hunting, and gathering in a complex economy that could not be considered "pure" hunting and gathering ... nor conventionally “agricultural." Ethnographic data (e.g., Griffin 1985; Rambo 1985) also suggest that historically forest adaptations were flexible and fluid, mixing cultivation, hunting, and trading strategies.

At Lake Thalee Song Hong, the ongoing pattern of burning and disturbance and the rapid turnover in species from the beginning of the Holocene in both the pollen and phytolith records, suggests that a managed arboreal economy, at least, began early in the Holocene to be followed by arboriculture by the mid- 
Holocene (combination of economic species and disturbance 6000-5000 в.P.). The dynamic changes in the vegetation are somewhat surprising for the lowland humid tropics, which are traditionally seen as culturally conservative backwaters.

If we return to the archaeological issues highlighted above, the proposed chronological and cultural "gap" (c. 1000+ years) between the Hoabinhian sites and the later Neolithic sites is not evident in the environmental record. The period from 8000-6500 B.P. appears to be a period of rapid forest expansion, but disturbance taxa and burning are still present. The sharp break suggested for the beginning of the Neolithic-with colonization by northern groups-at c. 4000 B.P., is not the first evidence for cultivation in this sequence. Economic plants (e.g., palms, banana, rice) appear by 5000 в.P. in the phytolith record, and possibly significantly earlier in the pollen record. Clear evidence of agriculture-or significant landscape modification - a pattern associated with the later Austronesian "expansion" of the first millennium в.c.- is present (disturbance taxa and indicators of slash-and-burn agriculture increase sharply) by 4000 B.P. The timing of environmental change does not correlate with the linguistic data, nor with the limited evidence from Malaysian rockshelter sites (Bellwood 1997). These data therefore suggest that the relationships between language and land use are more complicated than previously thought.

A major part of lowland Neolithic and specifically Austronesian subsistence is rice agriculture. If we look at the pattern of agriculture in the last 4000 years, there is limited evidence for rice cultivation in this area. While intensification occurs after 4000 в.P., it does not appear to be related to rice. The role of tree crops, and probably root crops (not directly revealed in the phytolith record), remains strong throughout the sequence (Maloney 1999). Maloney does suggest the possibility that "dry rice". was cultivated in the hills around this small lake, but the very limited evidence of rice in the phytolith sequence seems to suggest this was uncommon if not unlikely (rice phytoliths are taxonomically identifiable, where rice pollen is not).

In both the Neotropics and the Old World tropics an increasing corpus of evidence suggests that early Holocene tropical forests, both seasonal and humid, were managed. In the Americas herbaceous plants appear to be the main focus of early Holocene groups-root crops and maize (Piperno and Pearsall 1998). They argue that the seasonal tropics are the main focus of attention for lowland agriculture-and humid areas are marginal. In the humid tropics of Island Southeast Asia, however, there is evidence for long-term manipulation of plant species including arboriculture (Latinis 2000). While climatic changes during the late Pleistocene and early Holocene clearly played a role in major shifts in adaptation in many parts of the world, the choices made created very different regional trajectories of economic and cultural change.

\section{CONCLUSIONS}

The focus on the origins of rice agriculture has directed archaeologists away from the broader and often more interesting issues of how food strategies changed during and after the late Pleistocene. The management of places in the landscape to foster and concentrate economic resources is one critical strategy apparently used in both Island and Mainland Southeast Asia. 
Living in the tropical rainforest in southern Thailand during the Holocene appears to have involved attempts to manage the forest from its formation early in the Holocene. Depending on the definition of hunting and gathering used, this arboreal economy may well not have been a "pure" hunter-gatherer subsistence regime. Thus, for the early Holocene, in this tropical forest, aspects of Headland and Bailey's (1991) argument may be relevant.

The idea of a cultural and chronological gap between hunter-gatherer and expansionary agricultural groups is not supported by the environmental data. In addition, the transitions from one subsistence regime to another suggest a more complex, ongoing pattern of local and regional interaction rather than simple immigration.

The palaeo land-use data from Lake Thalee Song Hong, southern Thailand, provide not only the first late Pleistocene-Holocene environmental sequence for the Malay Peninsula, but also a regional contribution to understanding how people managed tropical rainforests during the Holocene. As is increasingly the case in the tropics, the palaeoenvironmental data provide a broad-based picture of a substantially earlier development of ancient subsistence regimes than indicated in site-based archaeology. These preliminary data for one area of southern Thailand, while providing new insights, underline the need for more systematic and intensive investigations of environmental (pre)history in Southeast Asia.

\section{ACKNOWLEDGMENTS}

The National Geographic Society supported the fieldwork for this project. The Colonial Williamsburg Foundation, Department of Archaeological Research, supported the laboratory analysis of the phytolith samples. I would particularly like to thank Peter Grave for his patient and insightful comments. Collaboration with the members of the Thailand Paleoenvironmental Project, and particularly the late Bernard Maloney, aided in the completion of this research.

\section{NOTES}

1. The project was part of a larger study of human environmental history in Thailand funded by the National Geographic Society. The author, J. White, and P. Grave collected two cores from Nong Thalee Song Hong in December of 1995.

2. Definitions of Holocene subepochs are notably inconsistent. I use the chronology defined by Nunn 1999: early Holocene 12,000-6000 B.P., middle Holocene 6000-3000 B.P., and late Holocene 3000 B.P. to present.

3. The basic $\mathrm{pH}$ of karst commonly affects pollen preservation; $\mathrm{pH}$ greater than 8 can also lead to phytolith dissolution.

4. Small rough spheres are found in a range of taxa. In this environmental context, they are indicators of disturbance and herbaceous taxa such as Euphorbiaceae. Euphorbiaceae pollen data follow a parallel trajectory through this sequence.

\section{REFERENCES CITED}

ADI, T.

1985 The re-excavation of the rockshelter of Gua Cha, Ulu, Kelantan, West Malaysia. Federal Museums Journal 30.

Allen, J.

1988- Agriculture, hydraulics, and urbanism at Satingpra. Asian Perspectives 28(2): 163-177. 
ANDERSON, D.

1990 Lang Rongrien Rockshelter: A Pleistocene-Early Holocene Archaeological Site from Krabi, Southwestern Thailand. Philadelphia: The University Museum, University of Pennsylvania.

Bailey, R. C., G. Head, M. Jenike, B. Owen, R. Rechtman, and E. Zechenter

1989 Hunting and gathering in the tropical rain forest: Is it possible? American Anthropologist $91: 59-82$.

BeLlWOOD, P.

1992 Southeast Asia before history, in The Cambridge History of Southeast Asia, From Early Times until c. 1800: 55-136, ed. N. Tarling. 2 vols. Cambridge: Cambridge University Press.

1993 Cultural and biological differentiation in Peninsular Malaysia. Asian Perspectives 32(1):3760.

1997 Prehistory of the Indo-Malaysian Archipelago. Revised ed. Honolulu: University of Hawai'i Press.

BOULBet, J.

1995 Towards a Sense of the Earth. Patani and Paris: Prince of Songkla University and CNRS.

Brosius, J. P.

1991 Foraging in tropical rain forests: The case of the Penan of Sarawak, East Malaysia (Borneo). Human Ecology 19(2):123-150.

BUTZER, K.

1996 Settlement histories, agrosystemic strategies, and ecological performance. Journal of Field Archaeology 23(2): 141-150.

Chang, Jen-hu

1984 The monsoon circulation of Asia, in Climate and Agricultural Land Use in Monsoon Asia: 334, ed. M. Yoshino. Tokyo: University of Tokyo.

Chappell, J., AND B. G. Thom

1977 Sea levels and coasts, in Sunda and Sahul: Prehistoric Studies in Southeast Asia, Melanesia, and Australia: 275-291, ed. J. Allen, J. Golson, and R. Jones. New York: Academic Press.

Courty, M. A., P. Goldberg, and R. MacPhail

1989 Soils and Micromorphology in Archaeology. Cambridge Manuals in Archaeology. Cambridge: Cambridge University.

Davison, G.

1991 Animal remains from the protohistoric community at Kuala Selinsing, Perak. Journal Arkeologi Malaysia 4:95-102.

DeBano, L., D. Neary, and P. F. Folliot, eds.

1998 Fire's Effects on Ecosystems. New York: John Wiley \& Sons.

DONNER, W.

1978 The Five Faces of Thailand: An Economic Geography. London: Hurst and Co.

DWyer, P. D., AND M. Minnegal

1991 Hunting in lowland, tropical rain forest: Towards a model of non-agricultural subsistence. Human Ecology 19(2): 187-212.

ENDICOTT, K., AND P. BeLLwoOD

1991 The possibility of independent foraging in the rain forest of Peninsular Malaysia. Human Ecolog $\gamma$ 19(2):151-185.

FARINA, A.

1998 Principles and Methods in Landscape Ecology. London: Chapman and Hall.

Flannery, T. F., and J. P. White

1991 Animal translocation. Zoogeography of New Ireland mammals. National Geographic Research and Exploration 7:96-113.

FLenLey, J. R.

1985 Man's impact on the vegetation of South-East Asia: The pollen evidence, in Recent Advances in Indo-Pacific Prehistory: 297-305, ed. V. N. Misra and P. Bellwood. New Delhi: Oxford and IBH Publishing Co.

1988 Palynological evidence for land use changes in Southeast Asia. Journal of Biogeography $15: 185-197$. 
Forman, R. T.

1995 Land Mosaics, the Ecology of Landscapes and Regions. Cambridge: Cambridge University.

Goldammer, J. G., and B. Seibert

1990 The impact of droughts and forest fires on tropical lowland rain forest of Eastern Borneo, in Fire in the Tropical Biota: 11-31, ed. J. G. Goldammer. Ecological Studies Vol. 84. Berlin: Springer Verlag.

Golson, J.

1977 No room at the top: Agricultural intensification in the New Guinea Highlands, in Sunda and Sahul: Prehistoric Studies in Southeast Asia, Melanesia and Australia: 601-638, ed. J. Allen, J. Golson, and R. Jones. London: Academic Press.

1989 Early agriculture in New Guinea, in Foraging and Farming: 678-687, ed. D. R. Harris and G. C. Hillman. London: Unwin Hyman.

Gorman, Chester F.

1971 The Hoabinhian and after: Subsistence patterns in Southeast Asia during the late Pleistocene and early recent periods. World Archaeology 2(3):300-321.

GosDen, C.

1995 Arboriculture and agriculture in coastal Papua New Guinea. Antiquity 69:807-817.

Grave, P., AND L. Kealhofer

1999 Assessing bioturbation in archaeological sediments using soil morphology and phytolith analysis. Journal of Archaeological Science 26(10): 1239-1248.

GRIFFIN, P. B.

1985 A contemporary view of the shift from hunting to horticulture: The Agta case, in Recent Advances in Indo-Pacific Prehistory: 349-352, ed. V. N. Misra and P. Bellwood. New Delhi: Oxford University Press.

Groube, L.

1989 The taming of the rain forests: A model for late Pleistocene forest exploitation in New Guinea, in Foraging and Farming: The Evolution of Plant Exploitation: 292-304, ed. D. Harris and G. C. Hillman. London: Unwin Hyman.

Haberle, S.

1993 Pleistocene vegetation change and early human occupation of a tropical mountainous environment, in Sahul in Review: Pleistocene Archaeology in Australia, New Guinea and Island Melanesia: 109-122, ed. M. A. Smith, M. Spriggs, and B. Fankhauser. Occasional Papers in Prehistory, No. 24. Canberra: Australian National University, Department of Prehistory.

1994 Anthropogenic indicators in pollen diagrams: Problems and prospects for late Quaternary palynology in New Guinea, in Tropical Archaeobotany: Applications and New Developments: 172-201, ed. J. Hather. London: Routledge.

Haberle, S., G. S. Hope, and Y. DeFretes

1991 Environmental change in the Ballem Valley, montane Irian Jaya, Republic of Indonesia. Journal of Biogeography 18:25-40.

Harlan, J. R.

1992 Crops and Man. $2^{\text {nd }}$ ed. Madison: American Society of Agronomy, Inc.

HARris, D. R.

1989 An evolutionary continuum of people-plant interaction, in Foraging and Farming: 11-26, ed. D. R. Harris and G. C. Hillman. London: Unwin Hyman.

HARRIS, D. R., ED.

1996 The Origins and Spread of Agriculture and Pastoralism in Eurasia. Washington, D.C.: Smithsonian Institution Press.

HASELDONCKX, P.

1977 The palynology of a Holocene marginal peat swamp environment in Jahore, Malaysia. Review of Palaeobotany and Palynology $24: 227-238$.

Hastings, P.

1983 Palynology and the vegetation development of a lowland peat swamp in Narathiwat, Thailand, in Proceedings of the Annual Technical Meeting, 1982: 122-131, ed. T. Thanasutipitak. Special Publication No. 4. Chiang Mai: Chiang Mai University, Department of Geological Sciences. 
Headland, T. N.

1986 Why Foragers Do Not Become Farmers: A Historical Study of a Changing Ecosystem and Its Effect on a Negrito Hunter-Gatherer Group in the Philippines. Ph.D. diss., University Microfilms Inc., Ann Arbor.

1987 The wild yam question: How well could independent hunter-gatherers live in a tropical rain forest ecosystem? Human Ecology 15(4) : 463-491.

Headland, T. N., and R. C. Bailey

1991 Introduction: Have hunter-gatherers ever lived in tropical rain forest independently of agriculture? Human Ecology 19(2): 115-122.

Headland, T. N., and L. A. Reid

1989 Hunter-gatherers and their neighbors from prehistory to present. Current Anthropology $30(1): 43-66$.

Higham, C.

1995 The transition to rice cultivation in Southeast Asia, in Last Hunters, First Farmers: New Perspectives on the Prehistoric Transition to Agriculture: 127-155, ed. T. D. Price and A. B. Gebauer. Santa Fe: School of American Research.

1996 The Bronze Age of Southeast Asia. Cambridge: Cambridge University Press.

Higham, C., and T. Lu

1998 The origins and dispersal of rice cultivation. Antiquity 72(278): 867-877.

HiLlen, R.

1984 Palynology of late Quaternary sediments from various tropical lowland depositional environments. Modern Quaternary Research in Southeast Asia 8:49-60.

Hodell, D. A.

1999 Paleoclimate of southwestern China for the past 50,000 yr inferred from lake sediment records. Quaternary Research 52:369-380.

Hope, G. S.

1977 Observations on the history of human usage of subalpine forest areas near Mt. Jaya. Irian $6: 41-72$.

1982 Pollen from archaeological sites: A comparison of swamp and open archaeological site pollen spectra at Kosipe Mission, Papua New Guinea, in Archaeometry: An Australian Perspective: 211-219, ed. W. Ambrose and P. Duerden. Canberra: Department of Prehistory, Research School of Pacific Studies, Australian National University.

Hope, G. S., AND J. Golson

1995 Late Quaternary change in the mountains of New Guinea. Antiquity 69:818-830.

Hope, G. S., and J. Tulip

1994 A long vegetation history from lowland Irian Jaya, Indonesia. Palaeogeography, Palaeoclimatology, Palaeoecology 109:385-398.

Hutterer, K.

1983 The natural and cultural history of Southeast Asian agriculture. Anthropos 78:169-212.

JiAng, Q., AND D. PiPERno

1999 Environmental and archaeological implications of a late Quaternary palynological sequence, Poyang Lake, southern China. Quaternary Research 52:250-258.

Kauffman, J. B., AND C. UhL

1990 Interactions of anthropogenic activities, fire, and rain forests in the Amazon Basin, in Fire in the Tropical Biota: 117-130, ed. J. G. Goldammer. Ecological Studies Vol. 84. Berlin: Springer Verlag.

KEALHOFER, L.

1996a Human environmental relationships in prehistory: An introduction to current research in South and Southeast Asia. Asian Perspectives 35(2):1-15.

19966 The human environment during the late Pleistocene and Holocene in Northeastern Thailand: Phytolith evidence from Lake Kumphawapi. Asian Perspectives 35(2):80-96.

1997 Evidence for Cultural Impact on the Environment During the Holocene: Two Phytolith Sequences from the Lopburi Region, Thailand. In South-East Asian Archaeology, 1992: Proceedings of the Fourth International Conference of the European Association of South-East Asian Archaeologists, Rome, 28th September-4th October 1992, edited by Roberto Ciarla and Fiorella Rispoli with the collaboration of Oscar Nalesini, pp. 1-20. Rome: Istituto Italiano per l'Africa e l'Oriente. 
2002 Changing perceptions of risk: The development of agro-ecosystems in Southeast Asia American Anthropologist 104(1): 178-194.

n.d. Phytolith morphology in Southeast Asian and Asian rices.

Kealhofer, L., And D. Penny

1998 A combined pollen and phytolith record for fourteen thousand years of vegetation change in Northeastern Thailand. Review of Paleobotany and Palynology 103:83-93.

Kealhofer, L., and D. Piperno

1994 Early agriculture in Southeast Asia: Phytolith evidence from the Bang Pakong Valley, Thailand. Antiquity 68(260):564-572.

1996 The phytolith record from Khok Phanom Di, central Thailand, in The Botanical Evidence, Excavation of Khok Phanom Di, vol. 4:237-248, ed. J. B. Thompson. London: Society of Antiquaries.

1998 Opal phytoliths in Southeast Asian flora. Smithsonian Contributions to Botany 88:1-39.

LATINIS, D. K.

2000 The development of subsistence system models for Island Southeast Asia and Near Oceania: The nature and role of arboriculture and arboreal-based economies. World Archaeology 32(1) : 41-67.

Liu, Kam-biu, Shuncai Sun, and Xinhe Jiang

1992 Environmental change in the Yangtze River Delta since 12,000 B.P. Quaternary Research $38(1): 32-45$.

MALONEY, B.

1980 Pollen analytical evidence for early forest clearance in north Sumatra. Nature 287:324326.

1985 Man's impact on the rainforest of west Malesia: The palynological record. Journal of Biogeography 1:537-558.

1991 The biological remains, part 1, in The Excavations of Khok Phanom Di, vol. 2:1-134, ed. C. Higham and R. Bannanurag. London: Society of Antiquaries.

1992 Late Holocene climatic change in Southeast Asia: The palynological evidence and its implications for archaeology. World Archaeology 24(1): 25-34.

1999 A 10,600 year pollen record from Nong Thalee Song Hong, Trang Province, South Thailand. Journal of the Siam Society 86(1-2):201-217.

Maxwell, A., AND K.-B. LiU

1996 Late Quaternary terrestrial pollen records from monsoonal areas of continental South and Southeast Asia. Paper presented at The Environmental and Cultural History and Dynamics the Australian-Southeast Asian Region, Melbourne.

Maxwell, A. L.

2001 Holocene monsoon changes inferred from lake sediment pollen and carbonate records, northeastern Cambodia. Quaternary Research 56:390-400.

Moran, E.

1991 Human adaptive strategies in Amazonian blackwater ecosystems. American Anthropologist $93: 361-382$.

MORLEY, R. J.

1981 The palaeoecology of Tasek Bera, a lowland swamp in Pahang, West Malaysia. Singapore Journal of Tropical Geography 2:49-56.

Newsome, J., AND J. R. Flenley

1988 Late Quaternary vegetational history of the central highlands of Sumatra. II. Palaeopalynology and vegetational history. Journal of Biogeography $15: 555-578$.

Nik Hassan Shuhaimi

1991 Recent research at Kuala Selinsing, Perak. Bulletin of the Indo-Pacific Prehistory Association $11: 141-152$.

Nunn, Patrick

1999 Environmental Change in the Pacific Basin: Chronologies, Causes, and Consequences. New York: John Wiley \& Sons.

O'CONNOR, S. J.

1986 Introduction, in The Archaeology of Peninsular Siam: Collected Articles from the Journal of the Siam Society 1905-1983: 1-10, ed. S. J. O’Connor. Bangkok: The Siam Society. 
Ogawa, H., K. Yoda, T. Kira, K. Ogino, T. Shidei, D. Ratanawongse, and C. Apasutaya

1965 Comparative ecological study on three main types of forest vegetation in Thailand. I. Structure and floristic composition. Nature and Life in Southeast Asia 4:13-48.

PeArsall, D.

2000 Paleoethnobotany. A Handbook of Procedures. $2^{\text {nd }}$ ed. San Diego: Academic Press.

PENNY, D.

2001 A 40,000 year palynological record from North-East Thailand: Implications for biogeography and paleoenvironmental reconstruction. Paleogeography, Paleoclimatology, Paleoecology 171:97-128.

PiPERNO, D. R.

1988 Phytolith Analysis: An Archaeological and Geological Perspective. San Diego: Academic Press.

Piperno, D., M. Bush, and P. Colinvaux

1991a Paleoecological perspectives on human adaptation in Panama. I. The Pleistocene. Geoarchaeology $6: 201-226$.

$1991 \mathrm{~b}$ Paleoecological perspectives on human adaptation in Panama. II. The Holocene. Geoarchaeology $6: 227-250$.

Piperno, D., and D. Pearsall

1998 The Origins of Agriculture in the Lowland Neotropics. San Diego: Academic Press.

Prell, W., W. Hutson, D. Williams, A. Be, K. Geitzenauer, and B. Molfino

1980 Surface circulation of the Indian Ocean during the Last Glacial Maximum, approximately 18,000 yr B.P. Quaternary Research 14:309-336.

Price, D., and A. Gebauer, eds.

1995 Last Hunters, First Farmers: New Perspectives on the Prehistoric Transition to Agriculture. Santa Fe: School of American Research.

RAmbo, A. TERry

1985 Primitive Polluters, Semang Impact on the Malaysian Tropical Rain Forest Ecosystem. Anthropological Papers, Museum of Anthropology, University of Michigan, No. 76. Ann Arbor: University of Michigan.

REN, X.

1984 Changes of the palaeoenvironment of southern East Asia since the late Tertiary, in The Evolution of the East Asian Environment: 419-578, ed. R. O. Whyte. Hong Kong: Centre of Asian Studies, University of Hong Kong.

Royal Survey Department

1969 Thailand: National Resources Atlas. Bangkok: Royal Thai Government.

SieveKing, G. DE G.

1954 Excavations at Gua Cha, Kelentan 1954. Part 1. Federation Museums Journal 1-2:75-143.

1956 The Iron Age collections of Malaya. Journal of the Malaysian Branch of the Royal Asiatic Society 29(2):79-138.

SMITINAND, T.

1976 A preliminary study of the vegetation of Surin Islands. Natural History Bulletin of the Siam Society $26: 227-246$

1980 Thai Plant Names (Botanical Names-Vernacular Names). Bangkok: Royal Forest Herbarium.

Stearman, A. M.

1991 Making a living in the tropical forest: Yuqui foragers in the Bolivian Amazon. Human Ecology 19(2): 245-259.

Steinke, S., and M. Kienast.

2001 A high-resolution sea-surface temperature record from the tropical South China Sea (16,500-3000 yr B.P.). Quaternary Research $55: 352-362$.

Sun, X., And Y. Chen

1991 Palynological records of the last 11,000 years in China. Quaternary Science Reviews 10:537-544.

Thanikaimoni, G.

1983 Pollen analysis, in Satingpra, I. The Environmental and Economic Archaeology of South Thailand: 51-58 and Appendix A, ed. J. Stargardt. Bristish Archaeological Reports International Series 158. Oxford: Archaeopress. 
TJIA, H. D.

1994 Global warming and long-term sea-level rise in Southeast Asia, in Implications of Expected Climate Change in the East Asian Seas Region: An Overview: 7-17, ed. L. M. Chou. RCU/ EAS Technical Report Series No. 2. Oxford and Kuala Lumpur: United Nations Environment Program.

1996 Sea-level changes in the tectonically stable Malay-Thai Peninsula. Quaternary International $31: 95-101$.

Verstappen, H. T.

1975 On palaeoclimates and landform development in Malesia. Modern Quaternary Research in Southeast Asia 1:3-35.

1980 Quaternary climatic changes and natural environment in Southeast Asia. Geojournal $4(1): 45-54$.

Whitmore, T. C.

1973 Euphorbiacae, in Tree Flora of Malaya, vol. 2:34-136, ed. T. C. Whitmore. London and Kuala Lumpur: Longman.

WORSTER, D.

1990 Transformations of the Earth: Toward an agro-ecological perspective on history. Journal of American History: Round Table: Environmental History 76:1087-1106.

YeN, D.

1998 Subsistence to commerce in Pacific agriculture: Some four thousand years of plant exchange, in Plants for Food and Medicine: 161-183, ed. H.D.V. Pendergast, N. L. Etkin, D. R. Harris, and P. J. Houghton. London: The Royal Botanic Garden, Kew.

Young, A.

1976 Tropical Soils and Soil Survey. Cambridge: Cambridge University Press.

Zhao, Z., AND D. Piperno

2000 Late Pleistocene/Holocene environments in the middle Yangtze River valley, China, and rice domestication: The phytolith evidence. Geoarchaeology 15(2):203-222.

ZHENG, Z., AND Q. LI

1999 Vegetation, climate, and sea level in the past 55,000 years, Hanjiang Delta, southeastern China. Quaternary Research 53:330-340.

\section{ABSTRACT}

The pollen and phytolith analysis of a 20,000-year lake core from southern Thailand provides the first long-term environmental sequence for this region. The evidence suggests that groups continuously occupied southern Thailand through both the early Holocene formation of the tropical rainforest and the transition from hunting and gathering to agriculture. Hunter-gatherers of the late Pleistocene apparently made the initial transition to the new tropical forest in the early Holocene by maintaining, expanding, or creating localized areas of disturbance or forest gaps to focus economic resources. KEYwords: palaeoenvironment, subsistence, Holocene, Thailand, phytolith analysis. 